\title{
From rebellion to martyrdom?
}

I am a child of DI-TII who is ready to sacrifice himself for Islam. Remember, oh mujahidin of Malingping, how our imam, S.M. Kartosuwiryo, built and upheld and proclaimed the independence of the Islamic state of Indonesia with the blood and lives of martyrs, not by relaxing and fooling around the way we do today. If you are serious about seeing the glory of the buried Islamic state of Indonesia rise again, shed your blood so that you won't be ashamed to face Allah, you who acknowledge yourselves to be children of DI-TII. ${ }^{1}$

Kartosuwiryo was executed in September 1962. His death was announced through a military communiqué, his body never released to the family and the place of his burial never made known. In the late years of Soekarno's premiership, after thirteen years of armed rebellion, Kartosuwiryo's body was not the focus of the public attention that would many years later be lavished on the coffins of the Bali Bombers Imam Samudera and Ali Ghufron, which were accompanied to Tenggulun, East Java, by large crowds in 2009. ${ }^{2}$ Kartosuwiryo's memoirs, if they existed, were not published, and the media only reported on his execution at a later date. Even today there is little certainty regarding the location of his burial, and after half a century of silent grieving, his grandchildren are publicly demanding DNA tests on a grave on Onrust Island, off the northern shores of Jakarta, which could be Kartosuwiryo's final resting place. ${ }^{3}$

This snapshot is symbolic of the changing debates about Kartosuwiryo, which rest at the centre of four broadly delimited stages in the development of public attitudes towards political Islam: condemnation, reconciliation and glorification; it is only since 2010 that works have appeared testing a fourth approach that aims at balancing the previous ones, a trend for the most part spearheaded by non-politicized authors.

1 Last Testament of Iqbal, alias Arnasan, alias Acong, October 2002. I am grateful to Ms Sidney Jones of the International Crisis Group, Jakarta, for sharing this document.

2 'Govt, media blamed for bombers' martyrdom', 10 November 2009, The Jakarta Post.

3 'Still a mystery after 45 years', in 'Kartosoewirjo', special edition, Majalah Tempo, 24 August 2010 , p. 46. 
In this final chapter I reflect on how the Darul Islam and Kartosuwiryo's actions were received and represented from 1947 until today. This is the final step in developing my argument on the contemporary relevance and legacy of the Darul Islam and Kartosuwiryo to Indonesian politics and Indonesian Muslims' identity.

SPECULATIONS AND THE RHETORIC OF BETRAYAL (1948-1950)

Kartosuwiryo's call for a holy war in West Java, it will be recalled, was first received positively by Minister of Defence Kasman Singodimedjo, who had given thanks to God for the bravery of Kartosuwiryo's actions. ${ }^{4}$ Yet, as the Indonesian Republic was gradually taking shape and relations between the regular army and the Islamic militias were worsening by the day, the Indonesian press in 1949 started condemning these 'wild troops' for creating disorder and undermining the nation-building process. We should read both press and intelligence reports published in the late 1940s and early 1950s against this backdrop, which has been explored in the previous two chapters.

Throughout the first months of 1948, the Dutch struggled to understand and to keep pace with the transformations of the West Java branch of Masyumi and its armed wings. At the same time, the name 'Darul Islam' occasionally appeared in Republican police reports. Even when officials had a sense of Darul Islam's and Kartosuwiryo's activities, they often misunderstood the group's nature and motives. In fact, the Darul Islam were not the only irregular troops, and the similarity in tactics made it extremely difficult for observers to ascertain who was behind the sabotaging of infrastructure. ${ }^{5}$

In 1949 and 1950, public discourse about Darul Islam's violence focused on the idea that the religious movement had been hijacked. In October 1949 Muhammad Natsir suggested that there were two 'kinds' of Darul Islam in Java - one truly committed to the country's independence and freedom from colonial domination, and the other one only interested in destabilizing the already fragile status quo. ${ }^{6}$

\footnotetext{
4 'Keterangan ringkas tentang Perang Sabil S.M. Kartosuwiryo', JogjaDoc no. 243, ANRI. See Chapter 3.

5 'Laporan No. 9/6/48 Perihal Darul Islam dll.nya didaerah Jawa Barat', 29 June 1948, JogjaDoc no. 203, ANRI.

6 'Daroel Islam ada toelen dan palsoe?', Sin Po, 26 October 1949.
} 
Even so, Dutch and Republicans could not agree on who was behind the supposed hijacking. The Dutch argued that it was an act of the communists, whilst the Indonesian press was keen on downplaying this possibility in favour of reading the D.I. as a 'Dutch Infiltration'.

\section{Darul Islam and communism}

The strings between the Darul Islam and communism were, on paper, tied very tightly. The first connection between the groups was drawn in June 1948. Yet it would only be after the Madiun Affair of September 1948 that Islamic and communist militias were portrayed in Dutch military reports as two faces of a single enemy, ready to cooperate to bring down the Republic. These reports considered Cirebon and Indramayu's Darul Islam troops to have the strongest communist character, with the PKI and the Darul Islam occasionally even sharing their headquarters. ${ }^{7}$ But it is evident that this was a localized reality, as in the south TII and PKI militias were conducting a war of propaganda aimed at garnering broader support at each other's expenses.

Dutch intelligence services noted the Darul Islam swelling in the aftermath of the Madiun Affair. After the Siliwangi Division had withdrawn from West Java in February-March 1948, these Republican soldiers were stationed just outside of Surakarta. By mid September the tensions between Republican forces and anti-government communist troops, whose stronghold was in Central Java, had escalated to a point of no return. PKI and the socialist Pesindo militias, estimated to number between 5,000 and 10,000 men, gathered in Madiun on 18 September, took control of the key points in the city and announced the formation of a new National Front (Front Nasional) government.

Musso - a prominent leader of the PKI in the 1920s, who had recently returned from Moscow after living more than twenty years overseas - was unable to counter Soekarno's calls for unity and Nasution's military attacks. The rebels were pushed out of the city and dispersed into the countryside, sparking violence between communists and PNI-Masyumi sympathizers. Musso was killed on 31 October. Amir Sjarifuddin was arrested and later executed by the Dutch because of his involvement in the events. Meanwhile Aidit fled for China, only to return a few years later to become Secretary General of PKI.

7 'Daroel Islam', 5 June 1948, APG no. 1002, NA; 'Rapport van Bk. Bandoeng inzake Islamitische stromingen in de residenties Priangan en Cheribon', AIntel, no. 1705, NA. 
In the aftermath of Madiun, Tan Malaka's 'national communism' became the only politically viable form of communism in Indonesia, at least until the second Dutch military aggression. Tan Malaka was eventually captured and executed by the TNI in February $1949 .{ }^{8}$ It would take another five years before communism could re-establish itself as a political force in Indonesia.

The first references to communist infiltrations in the Darul Islam ranks appeared in September 1948, when the Dutch uncovered both communist and Islamist literature and military badges in the same households in Ciawi. This discovery led the Dutch to argue that the communists, following their strategy of infiltration, had succeeded in taking over the Islamic movement. They drew further evidence from the Darul Islam's effort to redistribute land among the peasants, ${ }^{9}$ and the family connections between the Darul Islam and the left-wing Bamboe Roentjing militias. This much had already been suggested by the Indonesian press in April 1948.

The Dutch speculated that the Darul Islam had expanded into East Java, establishing a second Darul Islam group in the PonorogoBesuki-Jember area; this area had been hijacked by communists in September 1949 and had a different agenda and leadership than Kartosuwiryo's (actual) Darul Islam group in the Garut and Tasikmalaya districts. ${ }^{10}$ The Indonesian press responded to this theory by claiming that it was not a hijacking of the movement, but rather the case that the 'red' guerrilla were using the Darul Islam label to garner popular support and to provoke a greater political impact. ${ }^{11}$

In the following months this argument gained strength from additional speculations on Kartosuwiryo's past, advanced by the Indonesian army and Dutch information services: he was now portrayed as a "well-known communist and a prominent PKI leader in the Southeast Priangan since 1928'. This came as something of a surprise to the Dutch, as the report continued mentioning that 'it is utterly incredible that someone who has been a communist in the very dangerous years between 1928 and 1942 would now be a

8 Ann Swift, The road to Madiun, (Ithaca: Cornell Modern Indonesia Project, 1989).

9 KNIL report on 'Dar-ul-Islam beweging', 2 September 1948, AAS no. 2752, NA; 'Verbindingen tussen de 'Dar-ul-Islam'-beweging o.l.v. S.M. Kartosoewirjo en de Tan-Malaka-aanhang', 21 April 1949, AAS no. 2753, NA.

10 'Ponorogo: Daroel Islam', De Vrije Pers, 19 September 1949. The Dutch also attempted to argue that the Darul Islam had institutional presences in Panarukan, Jember and Mojokerto, but they also admitted that a plot to establish a Darul Islam group in Bondowoso had been uncovered in time to be stopped: 'And today here there is a communist government, and this is a strong one.' Logbericht, Soerabaja, 17 october 1949.

11 'Tak ada DI di Madiun Ponorogo?', Trompet Masjarakat, 5 October 1949; 'Lebih dikwatirkan provokatief daripada DI', Trompet Masjarakat, 12 December 1949. 
convinced religious politician'. ${ }^{12}$ The life of Kartosuwiryo was rewritten, and the origins of communism in Java were inextricably linked with the history of Sarekat Islam.

In this re-invented genealogy, the Sarekat Islam had initially been divided between Agoes Salim's cooperating group and the SI hijau ('green' SI), which in 1926 gave life to the Sarekat Rakyat and Alimin's PKI in Cirebon. But Salim's group also split, with Abikoesno and Kartosuwiryo taking the path of non-cooperation. In the aftermath of the first Dutch invasion, Masyumi and the Soeffah (Kartosuwiryo's educational institution) were transformed into the Majelis Islam in West Java to challenge the Dutch. ${ }^{13}$ In the light of Masyumi's mobilization of peasants and farmers, the party's favourable disposition towards the left wing (sayap kiri) and Tan Malaka's allegedly strong influence on several Masyumi leaders (including Wondoamiseno, Wahid Hasjim, Kartosuwiryo, Abikoesno, Wali Alfatah and Soetan Akbar), ${ }^{14}$ the Dutch had irrevocably established the connection between the Darul Islam and Tan Malaka's group. ${ }^{15}$

The Dutch connected the dots: Masyumi's roots in Sarekat Islam's Islamo-socialism, the individual backgrounds of party leaders, the overlapping of the military and political goals of the two factions, the labelling of Darul Islam actions as radical and anarchist, the Darul Islam and PKI's common interest in socio-economic justice and land distribution, and the infiltration of communist militias into the (apparently) emerging Darul Islam in East Java became solid foundation for their speculative argument.

The religious character of the Darul Islam was then described as a smokescreen, which at the beginning of the Cold War seemed a more logical assumption than rejecting entirely the possibility of a leftist infiltration, especially as "it could be assumed that the majority of the people in this country do not see the difference between communism or socialism and the social dimension of Islam' ${ }^{16}$

In 1950 the Dutch intelligence agency declared that all depended on local leaders and alliances, and as much as West Java

\footnotetext{
12 'Rapport betreffende MI, NII, TNII', 17 October 1948, APG no. 997, NA.

13 'Stukken betreffende verhoudingen tussen Communisme en Islam in Nederlands-Indië', AIntel no. 1706, NA.

14 "Verbindingen tussen de "Dar-ul-Islam"-beweging o.l.v. S.M. Kartosoewirjo en de Tan-Malaka-aanhang', 21 April 1949, AAS no. 2753, NA.

15 Harry Poeze has also pointed to the cooperation between the Darul Islam and the Gabungan Lasjkar Rakjat in West Java. See his Verguisd en vergeten: Tan Malaka, de linkse beweging en de Indonesische revolutie, 1945-1949 (Leiden: KITLV Uitgeverij, 2007), p. 1523. See also 'Verbindingen tussen de "Dar-ul-Islam"-beweging o.l.v. S.M. Kartosoewirjo en de Tan-Malaka-aanhang', 21 April 1949, AAS no. 2753, NA.

16 'Stukken betreffende verhoudingen tussen Communisme en Islam in Nederlands-Indië', AIntel no. 1706, NA.
} 
(especially Cirebon) had a strong communist influence, the roots of this cooperation were an opportunity and not ideological. ${ }^{17}$ In more recent times, the intellectual and writer Ahmad Tohari has suggested that the height of Darul Islam violence in the early 1960s, especially in Central Java, was connected with communist guerrillas readying themselves for the alleged coup of $1965 .{ }^{18}$

\section{The DI: A scheme of '(D)utch (I)nfiltration'}

The Indonesian press was unimpressed by the Dutch argument, and, as mentioned above, it often found valid counter-evidence to the 'communist Darul Islam' argument. The press instead argued that behind the group's expansion, and behind its most violent acts, were Dutch officers who were exploiting the current situation to destabilize the Republic and retain control over the colony.

During the 1945-49 period, some Dutch officers deserted the Royal Army to join Indonesian soldiers in support of various rebellious movements in the archipelago. The best known case is that of Captain 'Turk' Westerling, who had earned notoriety during his deployment in South Sulawesi and who, after the transfer of sovereignty, became the leader of an anti-Republican, pro-regional government army in West Java - the aforementioned Angkatan Perang Ratu Adil, or APRA. Mostly because of the territorial overlapping of Darul Islam and APRA activities, in early 1950 the Republican Army and the press became convinced that the two were working together. What is more, they believed that behind the Darul Islam's antagonism against Soekarno were the Dutch.

At the opening of the RIS parliament in February 1950, Soekarno 'blamed the groups that are staining the name of Islam with cruel and violent actions'. And Tempo magazine glossed:

What the President meant was the Darul Islam. Who pursues these cruelties though, whether it is really Kartosuwiryo's Darul Islam or

17 On the issue of Darul Islam and communism as discussed above see also: 'Communistische infiltratie in de Darul-Islam', Regentschapskantoor Garut, 6 July 1949, AAS no. 2753, NA; CMI Publication No. 97, 18 November 1948, AAS no. 3977, NA; 'Kort Overzicht van de houding van de Islam met betrekking tot de huidige politieke ontwikkelingen', 29 April 1949, in AMK Geheim 1901-1940: KVG no. F33, NA; 'Aantekeningen bij CMI publicatie van 5 Mei 1949 nr. 4797. Exh 10 Mei 1949, Kab Lett Z 42-2206, 1 June 1949, AAS no. 2754, NA; 'Nota', Batavia Police Commissar, 31 July 1949, AAS no. 2753, NA; 'Negara Islam Indonesia', 1953, AABRI DI; 'Nota betr. Darul Islam en Westerling, 2 February 1950, AMK Geheim 1901-1940: KVG no. T8, NA.

18 Ahmad Tohari, Lingkar tanah, lingkar air (Yogyakarta: LKiS, 1999), and interview with author, 31 April 2008, Purwakarta. 
a '(D) utch (I)nfiltration', is difficult to tell, perhaps because members of the DI-Kartosuwiryo pursue violent acts too, as its members have received incorrect information and thus bear a grudge towards those who are now considered their enemies.

\section{The article continued that}

it is known that at the beginning the DI was against the TNI because it felt abandoned in the occupied areas after the first Military Action [the July 1947 Dutch invasion] - yet the TNI had only abandoned some pockets. This resistance will increase, mostly because of the dangerous rumours that vilify the TNI. This is not an impossible development in the context of the propaganda conducted by reactionary groups like Westerling, which indeed envisage fragmentation and animosity amongst us. ${ }^{19}$

In the following years this argument was further refined, and as more NII documents showing the involvement of former Dutch officers became available, the government grew increasingly convinced that foreign, reactionary elements had infiltrated the regional uprisings. In 1956 it was even speculated that following protests from within the Darul Islam leadership, Kartosuwiryo could have been replaced as imam by Van Kleef, a former KNIL officer who had been in the ranks of the Darul Islam since $1949 .{ }^{20}$

Almost thirty years later, in 1977, a Siliwangi publication interpreted the Darul Islam as an extension of the colonial attempt to destabilize the newly established Republic, mildly admitting a possible underlying religious motive for the movement. ${ }^{21}$ One year later, the head of the Siliwangi Division, General Nasution, published his multi-volume history of the independence struggle, in which he openly attacked Kartosuwiryo as the internal enemy in the struggle against colonial oppression. ${ }^{22}$

19 'Bhinneka tunggal ika harus merupakan kenjataan', Majalah Tempo, 26 February 1950. Soekarno's quote also from Tempo.

20 Kementerian Penerangan, Republik Indonesia, pp. 213-35; 'Gerombolan di Djawa Barat', 28 September 1956, AABRI DI no. 23. More on Van Kleef's involvement in the Darul Islam can be found in Jackson, Traditional authority and national integration, pp. 428-32.

21 The book included a picture of Westerling's troops entering Bandung with the caption: 'On 23 January 1950, the APRA troops of the Just Prince entered Bandung to experiment with the establishment of the Islamic state of Indonesia (NII) with Bandung as capital city or to try to bring down the Pasoendan puppet state conceived of by Van Mook.' Madewa, Esa hilang dua terbilang, p. 92.

22 Abdul Haris Nasution, Sekitar perang kemerdekaan Indonesia (Bandung: Angkasa, 1978) pp. 15-6. 
MISSING IDEOLOGICAL REACTIONS TO KARTOSUWIRYO'S NII

The previous chapters showed that in the late colonial period and during the revolution, the Islamic state was seen as a viable platform for shaping the indigenous nation-state. It was not until around 1949 that the two trajectories of political Islam that had co-existed since the Japanese departure went their own separate ways: one became an engaged armed movement (the Darul Islam), alternately opposed and ignored by the other, the political front (Masyumi and its affiliates).

Masyumi's early calls for an Islamic state in 1945 had resonated across the country, and suggestions of an Islamized republic continued throughout the $1950 \mathrm{~s}$, as the party reiterated these calls until it was banned in 1960. Between 1948 and 1956, the debate on an 'Islamic state of Indonesia' thrived, both in magazines such as Aliran Islam (Bandung) as well as in book-length publications, often printed by Masyumi's printing houses in Bandung and Jakarta.

Yet one would be mistaken in thinking that Kartosuwiryo's NII found support, or became an inspiration, among these intellectuals. Whilst the party was fighting a political battle to ensure a diplomatic solution to the 'Darul Islam problem', those theorizing possible hybrids for an Indonesian Republic rooted in Islam, to be pursued through parliamentary consultation, did not acknowledge the developments that were taking place in West Java. Kartosuwiryo's theoretical elaboration and practical implementation of an Islamic state prompted no reactions, even as Masyumi ideologists were theorizing alternative options for an Indonesian Republic based on Islam. Kartosuwiryo's activism and writings, which until 1946-47 were part of Masyumi's apparatus, had been sidelined since he began his work towards creating an Islamic state in 1948.

In the following paragraphs I introduce briefly alternative conceptions of the Islamic state as elaborated by two political leaders. One is from the already mentioned Persis leader Isa Anshary; the other is from Masyumi intellectual Zainal Abidin Ahmad, who moved in the same circles as Kartosuwiryo in West Java. They tackled the same issues and had the same long-term vision for Indonesia. Yet it appears that Kartosuwiryo's blueprint of an Islamic state was neither embraced nor condemned, but rather ignored by these politicians.

Kartosuwiryo's experiment was not appreciably different from what these Masyumi intellectuals would suggest. However, their decision to 'stay in the game' implied a compromise, especially as the political climate continued to change. The fundamental 
difference lay in the political circumstances surrounding the drafting of these works, rather than in their religious-ideological stand. I suggest that it is because of these historical circumstances that Kartosuwiryo turns out to be more relevant to twenty-first century reformulations of Islamic polity than to his own contemporaries.

Isa Anshary first published Falsafah perdjuangan Islam in 1949, subsequently reprinted in 1951. In this booklet Anshary addressed issues pertaining to the Islamic state, including its foundations, its theological underpinnings and its form, making use only of Islamic sources. ${ }^{23}$ Anshary advocated the need to establish the Indonesian Republic on local cultural references (meaning Islam) rather than on foreign ideologies (Pancasila).

Engaging with the Pancasila, however, he strongly favoured making the underlying reference to Islam more explicit: he had a firm conviction that the sovereignty of God (ketuhanan) could only be understood in a state based on the Qur'an and sunnah that aimed to guide its citizens to salvation in this world and the next. The constitution's statement of ketuhanan, then, should have included a clear reference to Islam in order to guarantee the validity of the laws of God and to prevent people from 'thinking that they can have their own interpretation'. ${ }^{24}$

Zainal Abidin Ahmad (1911-83) was a Masyumi leader, a Sumatran of Minangkabau origins and the editor of Pandji Islam throughout the 1930s. His first systematic work was published in 1949 in Jakarta as Konsepsi tata negara Islam, re-printed as Konsepsi negara Islam (1952), and further expanded into Bentuk negara Islam in 1956, which included the original of 120 pages, plus 300 more. ${ }^{25}$

Different from Anshary, Zainal Abidin relied in equal measure on Western and Islamic thinkers, and he used both traditions to build his argument in favour of an Islamic state. Offering a glorified version of Western democracies, Zainal Abidin envisioned a binary structure, in which the Caliph represented the political authority and the Darul Islam was its socio-economic counterpart.

23 Anshary, Falsafah perdjuangan Islam (Medan: Saiful, 1951).

24 Anshary, Falsafah, pp. 172-5.

25 Zainal Abidin Ahmad, Konstitoesi negara, pendjelasan landjoet tentang oendang-oendang dasar negara Republik Indonesia (Bukit Tinggi: Poestaka Islam, 1946); Konsepsi tata negara Islam (Jakarta: Sinar Ilmu, 1949); Konsepsi negara Islam (Bandung: Al Ma'arif, 1952) and Membentuk negara Islam (Jakarta: Widjaya, 1956). In the meantime, Zainal Abidin Ahmad was also publishing about Islamic economics, and in the 1960s he translated Farabi's Ideal city: Zainal Abidin Ahmad, Dasardasar ekonomi Islam (Jakarta: Sinar Ilmu, 1950; 2nd ed. Jakarta: Pustaka Antara / Aida, 1952); Zainal Abidin Ahmad, Negara utama (madinatu'l fadilah), (Jakarta: Djambatan, 1964; 2nd ed. Jakarta: Kinta, 1968). 
In the introduction to its first edition, Zainal Abidin defined the Islamic state as 'an issue which long ago became an aspiration' for the Indonesian nation, and it is 'just because of the lack of understanding and knowledge of its form and modes, that at times we sense hesitation amongst our leaders'. Hence, he had engaged in this endeavour 'so that [this book] may reach the level of being studied in schools', as well as being read by the general public. ${ }^{26}$

Zainal Abidin expressed, in his 1952 Konsepsi negara, an understanding of the existing Republic as substantially resembling an Islamic state, but one in which institutions could be reformed to become stronger through their religious affiliation. Hence, in regards to the much debated principle of ketuhanan, Zainal Abidin expressed a different understanding of 'culture' from Isa Anshary, arguing that Soekarno's 'cultural ketuhanan' was 'a ketuhanan that holds firm tolerance', and 'a ketuhanan whose character and external features offer the people freedom to follow any religion they like'. This ketuhanan would be fully acceptable within the framework of an Islamic state. Further, he praised the Indonesian Republic for laying 'an important stone' in building a religious foundation for the state by establishing the Ministry of Religious Affairs and re-affirming the Pancasila itself. ${ }^{27}$ Yet, in the same text he offered suggestions for strengthening the religious character of the constitutional text, the structure and foundation of the state, its institutional features, the election of the head of state, the structure of religious bodies and of the education system, and more..$^{28}$

As domestic politics and the position of political Islam in Indonesia were changing, in 1952 Zainal Abidin had modified his approach. In the second revised edition of 1956 those instructions had disappeared, substituted by a general recommendation to draft a constitutional preamble 'briefly identifying the ideology and basics principles that will become the hukum abadi [eternal laws] of the state'. ${ }^{29}$ In this changed political environment, Zainal Abidin was testing intellectual avenues to affirm that the Indonesian Republic already was, substantially, an Islamic state.

Zainal Abidin's efforts to frame the current state as Islamic were made clearer in 1956, when he argued that 'there is no obstacle for each state to have its own slogan as dasar negara, so long as it doesn't undermine the four pillars [amanah, keadilan, ketuhanan, kedaulatan

Ahmad, Konsepsi tata negara Islam, 'Introduction' (Pendahuluan untuk tjetakan ke II).

Ahmad, Konsepsi negara, p. 43.

Ahmad, Konsepsi negara, p. 107.

Ahmad, Konsepsi negara, p. 107; Ahmad, Membentuk negara, p. 100. 
rakyat ${ }^{30}$ ] we have mentioned [as fundamental for an Islamic state], so it is not wrong if the Indonesian state recognizes the Pancasila mentioned in the constitution'. ${ }^{31}$

The minimum standard for a sound Islamic state was identified as having both a Muslim president and a majority Muslim population that would have the largest presence in the national and regional government bodies. To these two criteria Zainal Abidin added that Islam must be acknowledged as the ideology of the state, which already included the elements of an Islamic government. Yet he allowed that these Islamic elements might bear a different name (Pancasila, for example), so long as the law of the state does not contradict Islamic laws and the constitution guarantees mushawarah (consultation) and democratic principles. ${ }^{32}$ Arguably, in 1956 the Indonesian Republic was close enough to Zainal Abidin Ahmad's proposed Islamic state.

Zainal Abidin's writing consistently reflects the contemporary political situation of his time. As such, it is worth noting that in the context of the constitutional assembly Zainal Abidin argued that it was not enough to have Islam as 'founding ideology of the state', and that more substantial steps needed to be taken to consolidate the position of Islam in the Indonesian state. To support his argument, he cited the opinions of Islamic scholars on various Islamic constitutions, including those of Medina, the Abbasids, Turkey and Egypt. $^{33}$

BUILDING THE IMAGE OF A 'STERILE REBEL'

In the decades between 1950 and the mid 1990s, the Soekarno regime, the army and the New Order - with the tacit complicity of Islamic organizations - pursued a campaign aimed to portray the Darul Islam as a group of bandits who had attacked Dutch and Republican soldiers in equal measure, terrorizing the civilian population and destabilizing the country. Whether the Darul Islam was a channel for extended Dutch infiltration, communist activities or local grievances mattered little to the propagandists, and their explanations did not touch upon the movement's Islamic nature. In this environment, public discourse focused on the rhetoric of

30 Safety, justice, belief in God, people's sovereignty.

31 Ahmad, Membentuk negara, p. 76.

32 Ahmad, Membentuk negara, pp. 159-66.

33 Ahmad, Membentuk negara, pp. 14-5. 
national betrayal. Indonesian commentators depicted Kartosuwiryo as driven by self-interest and personal ambitions for political power, and his religiosity was labelled as 'mystical'. Kartosuwiryo's character was entirely sterilized of its ideological motivations, while the Darul Islam became associated with violence and, ultimately, with defeat.

Before outlining this second phase, however, I first turn to the Darul Islam's initial appearance in Western academic discourse and, arguably, to the last instance of Kartosuwiryo's being defined as a politician rather than a rebel or a martyr. In 1950 Van Nieuwehuijze described the Darul Islam as a movement that ignored calls for unity in the anti-colonial struggle in favour of outright confrontation in striving to establish an independent state of Indonesia solely based on Islam.

For Van Nieuwehuijze, 'the dār ul-Islām ideal is fulfilling the same function in Javanese society that is performed by revivalist movements in primitive societies [...] Amidst a socio-spiritual life that has been experiencing a deep shock, [the common man] is groping for values that possess certainty and permanence', while the 'supernatural authority' - a pattern of pre-Islamic societies - is embodied by the Islamic customary authority of the ulama. ${ }^{34}$ Here Kartosuwiryo was described as a Muslim politician dedicated to the anti-Dutch struggle, the leader of a terrorist movement and possibly a crypto-communist, for whom Islam is the common referent for an alternative paradigm to Western domination.

\section{Condemnation: Mysticism, violence and defeat}

As Indonesia was slowly settling into being an internationally recognized independent nation-state, the Ministry of Information led the first attempt to produce a national historiography project, publishing a series of volumes illustrating the history of each province. The volume on West Java appeared in 1953. Here the Darul Islam's activities are described as 'rotat[ing] around the individual aspirations of Kartosuwiryo', a man driven by feelings of political disappointment, fanaticism, religious dogmatism and adventurism. ${ }^{35}$

A pseudo-figurant (or 'fake leader') who used Islam as a tool to achieve governmental aspirations and who relied on political

34 C.A.O. van Nieuwenhuijze, 'The Darul Islam movement in Western Java', Pacific Affairs 23-2 (1950): pp. 181-2.

35 Kementerian Penerangan, Republik Indonesia, p. 232. In the same year volumes also appeared on Sumatra (North, South and Central), Sulawesi, Sunda Kecil and East Java. 
opportunism to rally popular support, Kartosuwiryo is an evil person, for whom it 'is better to die than to face defeat'. Kartosuwiryo emerges as a man dedicated to increasing his personal power, and for whom Islam is merely an instrument for gathering support. On this foundation, the ministry initiated a parallel discourse to Kartosuwiryo's motives: that of villagers' resistance and opposition to the Darul Islam. ${ }^{36}$

This same position was also taken by Western scholar Karl D. Jackson in the 1970s. A behavioural political scientist, Jackson argued that villagers in West Java decided whether or not to join the Darul Islam according to patterns of traditional authority, mirroring their village leaders. Islam, Jackson argued, was integral to the Darul Islam only so far as it supplie[d] groups that [we]re heterogeneous in their religious beliefs with a panoply of symbols that [could] be used to legitimize the leadership and ignite political action'. ${ }^{37}$ I shall not dwell further on this piece of scholarship, as Ruth McVey has systematically deconstructed Jackson's methodology and arguments, pointing to his inappropriate choice of applying a 'laboratory-like experiment' to a social movement. Jackson had rooted his study in a survey of more than 200 questions to a sample of villagers not really representative of the Priangan population, a choice that for McVey highlighted how Jackson did not have a comprehensive understanding of Islam or of Sundanese society. ${ }^{38}$ Jackson was, however, not the only scholar who opted to ignore the importance of Islam in Kartosuwiryo's activities and ideals on the basis of his 'mystic hence unorthodox' beliefs, as already discussed in the Preface and Chapter 1.

In the aftermath of Kartosuwiryo's capture and execution in 1962, the army and the government conducted a campaign presenting the Darul Islam as a terrorist movement supported by antinationalist and anti-Republican forces, whose costs were borne most heavily by the civilian population. Its religious-political goals and Kartosuwiryo's ideological depth were systematically flattened, and in combination with the absence of public debate on the subject, Kartosuwiryo slowly began to emerge as what I describe as a 'sterile rebel'.

36 Kementerian Penerangan, Republik Indonesia, pp. 218, 234-5. On p. 262 the picture of a village gathering bears the following caption: 'The Islamic community of Ciparay, under the leadership of its religious scholars, gathers in large numbers to cleanse the area of elements of the Darul Islam group that stir trouble.'

37 Jackson, Traditional authority and national integration, p. 126.

38 Ruth Thomas Mcvey, 'Reviewed work: Traditional authority, Islam, and rebellion: A study of Indonesian political behavior by Karl D. Jackson,' Pacific Affairs 54-2 (1981). 
Unlike the Dutch authorities in the 1920s-40s and Islamist activists in the 2000s, who highlighted the religious quality of Kartosuwiryo's actions, Indonesian commentators throughout the 1960s slowly erased religion from the picture. Earlier suggestions that Kartosuwiryo was a fanatic Muslim were quickly superseded by suggestions that he had markedly mystical tendencies. Amak Sjariffudin stressed how Kartosuwiryo was seen by his followers as a receiver of the wahyu Cakraningrat Sadar, bearer of the title of 'Representative of God to the entire Islamic community', and thus holder of traditional symbols of authority; this status was also demonstrated by him carrying a keris, a cundrik, and amulets. ${ }^{39}$ Sjariffudin's is the first description of Kartosuwiryo that unveils the underlying complexity, and perhaps even the internal contradictions, of his character as an Islamic leader.

The mixture of mysticism and religious fanaticism would become a recurrent theme; more importantly, it would become the foundation for arguing that Kartosuwiryo was not genuinely committed to an Islamic state. Because of his lack of formal religious education, his ignorance of Arabic and his own followers' belief in supernatural forces (elements first brought to light in a 1964 army-sponsored biography written by Pinardi), Kees van Dijk and Deliar Noer have argued that Kartosuwiryo was 'a dedicated sufist'. Because 'Sufism is almost the direct opposite of modernism', he 'definitely does not seem to fit into [Sarekat Islam's modernist] atmosphere', Van Dijk sentenced in 1981. ${ }^{40}$

The various political and scholarly approaches were supplemented by visual representations constructed by the military for wider public consumption. These memorabilia, pictures and graphic dioramas were publicized in museums and publications, and were often dedicated to highlighting the struggle against the Darul Islam.

One such museum is the Siliwangi museum in Bandung, which was opened in 1966 by Kartosuwiryo's captor, Ibrahim Ajie. The museum's collection focuses on the rebellion in West Java, highlighting the destruction carried out by the militias and the social involvement of the army in the post-conflict period. The most interesting pieces held here are the personal belongings of Kartosuwiryo and his wife at the time of their capture: he was reportedly holding a keris and a golok, whilst she was wearing a baju-sarong outfit. A large drum is placed right at the entrance to the gallery with a caption

39 Amak Sjariffudin, Kisah Kartosuwirjo, pp. 7, 20-1.

40 Van Dijk, Rebellion under the banner of Islam, pp. 8, 27-8, 391-6; Noer, The modernist Muslim movement, p. 148. 
stating that it was used to call Darul Islam soldiers to prayers. From this we can infer that the curators aimed to depict the couple and their followers as traditional Javanese and Sundanese characters, rather than as 'orthodox' or 'fanatical' Muslims.

At the same time that mysticism was being used to undermine Kartosuwiryo's dedication to the Islamic state ideal, the more general propaganda campaign continued to focus on the Darul Islam's betrayal of nationalist aspirations, as well as on its indiscriminate violence against civilians and on the defeat of a weak local movement by a strong unitary army.

After 1968 several publications commemorated the struggle of the Siliwangi troops in West Java against external and internal enemies, and attempted to belittle the Darul Islam movement's religious motivations, while emphasizing its violent overtones. With hardly an exception, Kartosuwiryo's character and personal dimension were absent from these books, as the focus shifted to the negative impact of the rebellion on the civilian population.

Yet, his name and face have remained omnipresent. The cover of Album peristiwa pemberontakan DI-TII di Indonesia summarized the numerous tales of the Darul Islam's terror that for years had been fed to the public: trains are derailed, villages ransacked and burnt down, peasants are running away with their newborns, while the TNI is bravely fighting the rebels. Kartosuwiryo's face is printed at the top of the page together with Daud Beureueh's, representing their similar leading role in such destruction.

These books show readers how dangerous the Darul Islam was, how violent and immoral their actions had been and how dedicated the Republican TNI was to reconstructing the affected areas in the 1960s. They also show how weak the movement had become, as the rebels' headquarters are pictured as shacks in the jungle and their leaders as either dead, defeated or captured. Since the mid 1950s, pictures of bloody militias have been shown next to healthy Republican soldiers. When Kartosuwiryo was included in the picture, he was usually portrayed as either bed-ridden or next to Colonel Ibrahim Ajie, invariably looking sick and emaciated from fighting, starvation and illness. ${ }^{41}$

41 The peak of TNI propaganda was reached with an exhibit of pictures showing Siliwangi soldiers rebuilding roads, schools and mosques all over the Priangan region, the heartland of the rebellion. Interestingly, these images of the army's role in rebuilding the region are not present in the army's own publications, but instead dominate the scene in army museums. Other symbolic images include those of Kartosuwiryo being 'returned to civilization' as his hair is cut, and those of him facing the reading of his death sentence. Madewa, Esa hilang dua terbilang. 
In its first decade, the New Order regime dedicated considerable attention to separating the social and political dimensions of Islam. Throughout the 1970 s political Islam became the bete noire of the regime, whilst at the same time Suharto pushed individual piety as an anti-communism policy. The building of mosques and the encouragement to attend sermons under repressive rule transformed these places of worship into the only available spaces for youths' and dissidents' gatherings and discussion. When these local manifestations of Islamic piety met with the ongoing international Islamic revival, the radicalization of Islam - whether political or spiritual - was almost inevitable.

On the other hand, the government merged all Islamic parties into the Partai Persatuan dan Pembangunan (PPP, Unity and Development Party) to ensure that religious groups would not benefit from the elimination of communism and to capitalize on the different souls of the religious movement. The senior leadership of Masyumi still advocated some combination of state and religion, whilst the younger generation called for a renewal of Islam, arguing that the Islamic state was now a mirage. ${ }^{42}$

The results of the elections of 1977 were not appreciably different from those of 1971 in number: the Golkar government party maintained its $62 \%$ majority; the nationalists, rearranged into the Partai Demokrat Indonesia, or PDI, slid from $10 \%$ to $8.6 \%$, and the PPP Islamic party was still just under $30 \%$. Yet, in the time between the two elections, Golkar's approach to Islam had changed dramatically. As R. William Liddle has pointed out, 'In 1971 Golkar had had a strongly anti-Islamic image and had actively cultivated the support of the abangan [nominal Muslims], who fear a theistic state should political Islam come to power. By 1977 Golkar had many local Islamic teachers in its camp [...] and used them to counter PPP arguments that Muslims were obliged to choose the Ka'abah,' meaning voting for the PPP. ${ }^{43}$

In the long term, the New Order's support for Islamic piety and its repression of its political expressions backfired, much as similar Dutch efforts had in the late colonial period.

\section{Reconciliation: keep your friends close, but your enemies closer}

The campaign that for decades had condemned Kartosuwiryo and his movement as anti-Republican and anti-national came to a halt

42 Hefner, Civil Islam, pp. 100, 126.

43 R. William Liddle, 'Indonesia 1977: The New Order's second parliamentary election', Asian Survey 18-2 (February 1978): pp. 175-85; quote on p. 181. 
in the early 1980s. The denunciation of Kartosuwiryo was first softened and then suspended. When it was replaced years later, it was with a new critique that distinguished between the means and the goals of the struggle, bearing witness to Suharto's attempted reconciliation with Islamic groups in the late 1980s and mid 1990s.

Before this new wave of critiques, however, in 1983 Suharto announced the asas tunggal policy, according to which all organizations and parties had to affirm their foundation in the Pancasila. Whilst this policy was intended to eradicate Islam from politics $\mathrm{NU}$, for example, refused to abide by this principle and withdrew from politics - its unintended outcome was that now religion could no longer be confined to one party (the PPP), and religiously informed politicians could now spread their influence across the political stage. Several Nahdatul Ulama leaders lent their support to Golkar during the electoral campaign of 1987, and the PPP lost more than $10 \%$ of its votes. ${ }^{44}$

The 1980 s were marked by three important phenomena: the religious revival, the secularists' increasing interest in democratic reforms and the military's mild opposition to Suharto. During this time, Suharto began to see conservative Muslims as suitable new allies, and the New Order changed its attitude towards Islam.

The tension between the ideological and violent aspects of the Darul Islam are probably best represented in the ABRI museum Waspada Purbawisesa, the Museum of Eternal Vigilance. This museum was opened in Jakarta in November 1987 by Suharto, with the objective of "present[ing] some of the historical facts surrounding the cruelty of DI-TII terrorism' and with the intention of 'building and placing on a solid foundation the nation's determination to preserve the Pancasila and the 1945 Constitution' ${ }^{45}$ The museum exhibits charts, maps, pictures, archival documents, miniatures and memorabilia laid out in such a manner as to establish an intelligible framework for the TNI operations against the Darul Islam across the archipelago.

Katharine McGregor has claimed, in her History in uniform, that 'a visitor to the Museum of Eternal Vigilance is provided with only one motive for the Darul Islam rebellions: the establishment of an Islamic state' ${ }^{46}$ However, as a visitor I did not have the same impression, and the group's religious motivations do not appear as evident

44 Hefner, Civil Islam, pp. 167-8. PPP went down from $27.8 \%$ in 1982 to $16 \%$ in 1987

45 Museum Waspada Purbawisesa, Museum Waspada Purbawisesa: Buku panduan. 3rd ed. (Jakarta: Markas Besar Angkatan Bersenjata RI, Pusat Sejarah dan Tradisi ABRI, 1997 [1995]), p. iii. 46 Katharine E. McGregor, History in uniform: Military ideology and the construction of Indonesia's past (Singapore: NUS Press, 2007). 
as its violent means. Within a few years after the museum's opening, the story was to change. Despite there being very little evidence to indicate the Darul Islam's dedication to the Islamic cause, the guide to the building, published in the mid 1990s, describes Kartosuwiryo as having been committed to the Islamic state since 1938 and contextualizes the Darul Islam's actions within the framework of the Islamic political cause and the anti-colonial struggle. ${ }^{47}$ I suggest that this change, which in the long term helped the elaboration of alternative, positive visions of the movement, was the result of the state's new relation with Islam. By the early 1990s, Suharto had relaxed limitations to public displays of religion and had strengthened his own Islamic credentials. The regime allowed headscarves and increased the offering of religious subjects in state schools, widened the powers of Islamic courts and recognized the Palestinian Authority. The presidential family went on hajj and supported the opening of the first Islamic bank. Catholic officers were replaced by 'Green Generals', more sympathetic towards Islam. Also, the conservative Ikatan Cendekiawan Muslim Indonesia (ICMI, Association of Muslim Intellectuals) was established..$^{48}$

Yet an underground rapprochement had already started as early as the 1960s. Under the cover of New Order repression, political Islam had come to represent the new enemy, but as the autocratic regime required a careful balancing of forces, the secret services orchestrated occasional releases of pressure. This great scheme of co-optation was doomed to fail, as former members of the Darul Islam were not prepared to be played as puppets and sought instead to take advantage of the movement's guided reorganization to reconnect with each other and regain their strength.

The Darul Islam had been officially disbanded in 1962, when the movement's top leaders signed a Joint Proclamation (Ikrar Bersama) acknowledging that they had been 'wrong and misguided' and affirming their allegiance to the Republic. Yet the quashing of the rebellion and the curbing of the Islamic state dream did not imply the total disappearance of the movement. In the 1960s the army made occasional use of its militias, as was the case during the alleged coup of 30 September 1965, for example, when former Darul Islam members in West Java and northern Sumatra were given weapons to attack suspected communists. In the words of a Darul Islam veteran, 'Between 1962 and 1968, the Islamic state of Indonesia was buried by the worldly facilities that the enemy provided'. ${ }^{49}$

49 Jones, 'Recycling militants', pp. 2-3. 
As Suharto was consolidating his newly acquired power, the disbanded Islamic Army offered an appealing pool of unofficial military supporters, especially as their collaboration was granted on the expectation that Islam would substitute communism as the new ideological ally of the state.

In the early 1970s the New Order continued to press forward with its co-optation policies, and the Badan Koordinasi Intelijen Negara (BAKIN, National Intelligence Coordination Body), under Ali Moertopo's guidance, became involved in the reconstruction of the NII leadership. In 1973 Daud Beureueh was made a military commander, and the following year he became imam. Yet once the movement's resurrection had been secured, tensions were quick to emerge. Daud Beureueh's policy of 'diplomacy and consolidation' caused the first split in 1976, when Gaos Taufik - a former Hizboellah and Darul Islam member from Garut - deemed the times ripe to re-open a jihad front and created Komando Jihad as a jihadist re-embodiment of Kartosuwiryo's group. Moertopo's creation had released itself from the tight embrace of the government: at the end of the decade power struggles fragmented the organization, and Adah Djaelani - a first-generation fighter from West Java who had been co-opted by BAKIN in the early 1960s bypassed Daud Beureueh and rose to the position of imam. He then reinstated Kartosuwiryo's sons and original associates back into the dewan imamah. ${ }^{50}$

The fragmentation of this new Darul Islam did not lead to the fading of its activities, but rather to their proliferation. By the late 1970s Komando Jihad had expanded its operations to Sumatra and Flores, leading the police to crack down on the entire organization between 1979 and 1982. Adah Djaelani was also arrested, and by 1986-87 it had become clear that the movement could not proceed without an acting imam. The election of Masduki transformed yet again the outlook of the Darul Islam, most importantly by fostering the development of its international connections. In the changed context of the mid 1980s, Abu Bakar Ba'asyir and Abdullah Sungkar often travelled to Afghanistan and the Middle East. The goal of an Islamic state of Indonesia evolved into that of a transnational caliphate. ${ }^{51}$

In the years that followed, this jihadist soul of the Darul Islam alienated the sympathies of those committed to the socio-reli-

50 Jones, 'Recycling militants', p. 22.

51 Jones, 'Recycling militants', pp. 2-3. For more details on Darul Islam's re-embodiments in the 1970s-90s, see Quinton Temby, 'Imagining an Islamic state in Indonesia', Indonesia 89 (April 2010): pp. 1-36. 
gious advancement of the ummah, including the usroh movement, inspired by the Egyptian Muslim Brotherhood. This jihadist faction eventually became the Jemaah Islamiyah in 1993. The Darul Islam movement was, overall, rarely weakened by these splits, as it was able to absorb their impact by multiplying and differentiating its strategies and priorities. It gave birth to the cell-based usroh movement, the institutional Majelis Mujahidin Indonesia and the international jihadist Jemaah Islamiyah: in the words of a Darul Islam member, 'The Darul Islam is a house with many rooms, enough for all the factions'. ${ }^{52}$

In late November 1997, seventeen activists were arrested in Solo on the heels of a number of other arrests in West and Central Java. During the raid, the police reportedly found only one book, and it was about Kartosuwiryo and his struggle. Interviewed on the issue, a commentator declared: 'This NII that we have now cannot be separated from the first NII. ${ }^{53}$

What has kept these various factions under a single roof is Kartosuwiryo's project of establishing a Negara Islam Indonesia. The deep desire to revive Kartosuwiryo's memory and goals has led to his public re-interpretation as hero and model in the post-Suharto era.

\section{Glorification}

From 1962 onwards, the Indonesian government and military apparatus worked hard to erase the memory of Kartosuwiryo as a nationalist politician as well as a religiously inspired leader, instead promoting a single image of him as a separatist rebel whose actions were directly aimed at fragmenting the unitary republican state. However, since the end of the New Order regime in 1998, we have witnessed a proliferation in alternative visions of this 'enemy of the state', now often portrayed as a martyr.

I have suggested that the transformation of the portrayal of the Darul Islam and Kartosuwiryo - from enemy of the nation, to absentee, to dedicated Muslim - should be read as mirroring the transformations in public attitudes towards Islam. As noted above, the government's sterilization of Kartosuwiryo was heralded by the obliteration of his religious dimension (of both his character and his movement's rebellion) and his gradual disappearance from public discourse in the 1970s-80s. Yet in the long-term, this

52 Darul Islam members' saying in Jones, 'Recycling militants', p. 31.

53 Panji Masyarakat, 'Impian para pendukung Kartosuwirjo', 24 November 1997, pp. 16-8. 
approach of the New Order created an empty space, ready to be filled once the state and its tight-fisted control of public narratives had been weakened.

Suharto's attempts to invert the decades-old outright condemnation of the Darul Islam had not gone far enough: public discourse was still saturated with negative depictions of the struggle when the relaxation of restrictions on the press, the increasing reach of the Internet and the growing use of blogs allowed the proliferation of alternative visions of history in the post-reformasi era. These developments ultimately resulted in the emergence and rapid spread of hagiographical depictions of Kartosuwiryo's life.

This literature ought to be seen as one aspect of a more general process of the re-Islamization of the public sphere that has been taking place since 1999, and is deeply embedded in the political agendas of groups interested in a religious revival. In fact, the authors who have been involved in rehabilitating Kartosuwiryo's memory are often the same actors who have been active in the effort to implement sharia law and to resurrect visions of an Islamic state. As the name of Kartosuwiryo has gradually disappeared from government-sponsored materials - he is barely mentioned in Indonesian text books, for example - these positive depictions of his life and legacy have contributed to creating an aura of respect and admiration for him, which in turn has led to the creation of a new role model, a hero and martyr for Islam.

The first author who has looked at Kartosuwiryo from this new perspective is $\mathrm{Al}$ Chaidar, a former member of the new Darul Islam movement in Jakarta and supporter of the Islamic state project, who graduated from Universitas Indonesia (Depok, Jakarta) in 1996 having written a thesis on the Islamic state ideology in Southeast Asia. Al Chaidar has produced several titles on the theory of the Islamic state and Kartosuwiryo's experiment. Yet he has not taken the opportunity to offer a critical assessment of Kartosuwiryo's ideology and actions, limiting his scope instead to describing events in a supportive and apologetic tone..$^{54}$

Another productive author has been Irfan Awwas, the secretary of the Majelis Mujahidin Indonesia (MMI, Indonesian Coun-

54 Al Chaidar, 'Ideologi Negara Islam di Asia Tenggara: Telaah perbandingan atas terbentuknya diskursus politik Islam dalam gerakan-gerakan pembentukan negara di Indonesia dan Filipina pasca kolonialisme' (thesis, Universitas Indonesia, Jakarta, 1996); Al Chaidar, Wacana ideologi negara Islam (Jakarta: Darul Falah, 1998); Al Chaidar, Pemikiran politik; Al Chaidar, S.M. Kartosoewirjo: Pemberontak atau mujahid (Jakarta: Suara Hidayatullah, 1999); Al Chaidar, Sepak terjang K.W.9 Abu Toto menyelewengkan N.K.A.-N.I.I. pasca S.M. Kartosoewirjo, revised ed., vol. 1, 'Serial musuh-musuh Darul Islam '(Jakarta: Madani Press, 2000). 
cil of Mujahidin). He was also the editor-in-chief of Arrisalah, until the magazine was shut down and Awwas sentenced to nine years in prison for activities associated with the NII movement. ${ }^{55}$ Among others, Awwas has written on the figure of Kartosuwiryo in 1999 and on the Islamic state ideology in 2007; another book, published the following year, compares Kartosuwiryo, Daud Beureueh and Kahar Mudzakkar as NII leaders. ${ }^{56}$ Many periodicals have also engaged this newer perspective on Kartosuwiryo's legacy. One example is a magazine titled Majalla Darul Islam, edited by $\mathrm{Al}$ Chaidar, which is specifically dedicated to issues related to the establishment of an Islamic state of Indonesia and the spread of Kartosuwiryo's writings and ideology. Sabili, edited by Herry Nurdi, similarly dedicates itself to spreading Kartosuwiryo's writings and incorporates numerous contributions from both Awwas and Chaidar. ${ }^{57}$

As is clear from the books' titles and the authors's backgrounds, these publications fed into the propaganda for an Islamic state and did not criticize any aspect of Kartosuwiryo's struggle. Both Chaidar and Awwas, despite holding the benefit of privileged information and networks, failed to provide a complete assessment of Kartosuwiryo's leadership and character. Blinded by their personal beliefs, they avoided acknowledging the violent aspects of the Darul Islam's operations, univocally blaming all actions of terror on infiltrated army soldiers or communist militias.

Kartosuwiryo emerges as the patron of the Islamic state, a man who gave his life for its ideals and their realization and who fell victim to secular forces. In representing him as such, though, Kartosuwiryo's advocates have made the same mistake as New Order propagandists: hiding certain aspects of the story, the integrity of the authors and the truthfulness of their accounts have been called into question, thus alienating the sympathies of those who might be inclined towards considering Kartosuwiryo an Islamic nationalist and an important figure in the independence struggle. This

55 Noorhaidi Hasan, Laskar Jihad: Islam, militancy, and the quest for identity in post-New Order Indonesia (Ithaca: Southeast Asia Program Publications, Cornell University, 2006), pp. 18-9. I am grateful to Martin van Bruinessen for suggesting that probably the very first attempt at 'glorification' was an article in al-Ikhwan magazine later to become Arrisalah, likely written by Irfan Awwas himself in the early 1980s.

56 Irfan Awwas, Menelusuri perjalanan jihad S.M.Kartosuwiryo: Proklamator Negara Islam Indonesia (Yogyakarta: Wihdah Press, 1999); Irfan Awwas, Jejak jihad S.M. Kartosuwiryo. 3rd ed. (Yogyakarta: Uswah, 2007); Irfan Awwas, Trilogi kepemimpinan Negara Islam Indonesia (Yogyakarta: Uswah, 2008).

57 Herry Nurdi, ‘S.M. Kartosoewirjo: perlawanan dari Malangabong', Sabili 11-9 (2003). 
vision, in fact, is now embraced by liberal secular publishers such as Gramedia and Tempo (see below).

In the post-reformasi context, amid heavy criticism of the army and within the framework of a surging Islamic consciousness, condemnatory portrayals of Kartosuwiryo have been shunned in favour of new ones. In an effort to bring him forward as a model of Islamic leadership in contemporary Indonesia, Islamist authors actively adjust representations of Kartosuwiryo's religiosity to conform with renewed standards of orthodoxy, often denying or ignoring the mysticism that had been relevant to his leadership in 1940s-50s Java. ${ }^{58}$

\section{KARTOSUWIRYO AND CONTEMPORARY VISIONS OF ISLAMIC LAW}

IN INDONESIA: THE HUKUM PIDANA OF 1949 AND THE MMI CODE OF 2005

The congress that gave birth to the MMI was opened by Irfan Awwas under the banner of being the 'first national congress of mujahidin'. It was attended by some 2,000 people from different backgrounds and organizations, all interested in calling for full implementation of sharia law and rejecting anything that was against Islam. The leadership of the movement was for several years shared between Irfan Awwas, as chairman of the executive committee, and the senior Hadrami cleric Abu Bakar Ba'asyir, nominated amir ul-mujahidin. Ba'asyir, alongside Abdullah Sungkar (a key figure in the Jemaah Islamiyah), was crucial in creating a network of like-minded activists through the establishment of the conservative pesantren al-Mukmin in Ngruki, near Solo, in the early 1970s. However, according to Noorhaidi Hasan, during Ba'syir's and Sungkar's more than twenty years of self-imposed exile in Malaysia, it was Irfan who had ensured the revival of the efforts to establish a caliphate and an Islamic state by constituting once again the Negara Islam Indonesia. ${ }^{59}$

The use of NII terminology is neither generic nor casual, as recent research has brought to light the genealogical connections between Kartosuwiryo's Darul Islam movement in West Java and the Islamist groups that emerged between the 1970 s and today. ${ }^{60}$

\footnotetext{
58 Awwas, for example, in reporting Kartosuwiryo's psychological evaluation subtly censors the sentences that suggested that Kartosuwiryo's mysticism was an aspect of his intelligence.

59 Noorhaidi Hasan, Laskar Jihad, pp. 18-9, 47.

60 See the recent work done by the International Crisis Group in Jakarta; Martin van Bruinessen, 'Genealogies of radical Islam in post-Suharto Indonesia' (2002), Utrecht University Website, at http://www.let.uu.nl/ Martin.vanBruinessen/personal/publications/ genealogies_ islamic_radicalism.htm; Greg Fealy's ongoing research; and Quinton Temby's doctoral research.
} 
Based on the connections already highlighted between Kartosuwiryo and contemporary Islamist circles, I also advance the hypothesis that the MMI's sharia code, drafted in 2002 (and re-drafted in 2005), should be analysed in comparison with the 1948-49 NII's Criminal Code, the Hukum pidana.

Tim Lindsey and Jeremy Kingsley have argued that the MMI code finds its origins 'beyond Indonesia's shores', more specifically, in Malaysia, where the Islamist Parti Islam Se-Malaysia (PAS, Pan-Malaysian Islamic Party) party ratified sharia criminal codes in Kelantan in 1993 and in Trengganu in 2003. They further suggest that Zia ul-Haqq's legal reforms in Pakistan and Saudi Arabia's Wahhabi madhhab influenced, in more and less direct ways, the drafting of the code.$^{61}$ It is my contention, instead, that even though it is admissible that Malaysia and Pakistan had a political influence on the MMI, there was no need for Lindsey and Kingsley to look so far away, as a substantially similar criminal code had been compiled by Kartosuwiryo in Java in 1949, which mostly reflected a traditional Shafi'i interpretation of fiqh. In addition to geographical proximity, during my research I have noticed that the ideological connections with, and respect for, Kartosuwiryo and the NII amongst Indonesia's sharia-minded activists is still strong, and his texts are widely read and circulated. According to the introduction to the 2005 code, the MMI had set up a Komisi Khusus (Special Commission) to produce a text that would enable 'each Muslim to easily understand the matters of the Islamic criminal code, so as to be ready to support an integral enforcement of Syariat Islam', ${ }^{62}$

The two formative texts of Kartosuwiryo's NII were the Constitution and the Criminal Code. I suggest that differences in these two documents, issued one year apart from each other, reflect a change in political priorities, a consequence of the transformed military context and the changing relationship between the Islamic state and the Indonesian Republic. With the Constitution, Kartosuwiryo gave the NII a political-administrative structure, the same goal pursued by Masyumi intellectuals in the 1950s. But with the Criminal Code, Kartosuwiryo shifted the focus away from governance and

61 T. Lindsey and J. Kingsley, 'Talking in code: Legal Islamisation in Indonesia and the MMI shari'a criminal code', in Peri Bearman et al. (eds), The law applied (London: I.B.Tauris, 2008), pp. 295-320; quote on p. 309.

62 'Proposal for a Criminal Code for the Republic of Indonesia adjusted to accord with the Syari'ah of Islam', issued by the central headquarters of the Majelis Mujahidin, Jl.Veteran no. 17, Jogjakarta, Indonesia. I have here used the English translation of this 2002 draft, kindly provided by Jeremy Kingsley. Fauzan Al-Anshari, KUHP Syariah dan penjelasannya (Jakarta: Departemen Data dan Informasi MMI, 2005). 
towards the day-to-day lives of the Islamic state's citizens. The same concern is at the root of the MMI's effort to draft a criminal code based on Islamic precepts, and the issue of the government's structure is not touched upon.

The reasons for Kartosuwiryo's establishment of the NII before the achievement of a 'perfect' Muslim society can be found in the peculiar political context of 1949; as noted above, the Darul Islam originally called for a gradual transformation of West Java's society into an Islamic state. The doors to implementing this project had opened with the anti-colonial struggle, only to be shut by the Dutch invasion of West Java and the later inclusion of this region in the Pancasila Republic. At that point, all which the Darul Islam could concern itself with was the regulation of the daily lives of those resident in the areas it controlled.

Half a century later, with the fall of the Suharto regime and the opening of the debate on what direction Indonesian politics should take, the majority of Islamic groups began their campaign for a stronger, more formal presence for religion in society, without an open challenge to the Republican structure. With the restoration of democratic institutions, Islam has made a comeback in parliament, and with respect to constitutional amendments, the question of the Jakarta Charter and sharia law once again came under the spotlight between 1999 and 2002. Interestingly, of the twenty-one Islam-based parties allowed to compete in the general elections of 1999, only four campaigned for the transformation of the Indonesian Pancasila Republic into an Islamic state, but fourteen lobbied for the inclusion of Qur'anic laws into the civil and criminal codes. They have channelled their efforts towards drafting a criminal code in compliance with the sharia, but not necessarily as part of a state based on Islam.

This trend helps make clear why MMI has insisted that legislation be based in the sharia, which would be considered more acceptable and therefore potentially more influential, rather than that the government be entirely Islamic. None of the proposed amendments passed, and the Jakarta Charter was officially rejected in August 2002. However, since 2000 several local regulations, or peraturan daerah, have been passed at the provincial and district levels to introduce legislation in accordance with sharia. ${ }^{63}$

63 Robin Bush, 'Islam and constitutionalism in Indonesia', in David Linnan (ed.), Legitimacy, legal development and change: Law and modernization reconsidered (Surrey, UK: Ashgate, 2012); Robin Bush, 'Regional Sharia regulations in Indonesia: anomaly or symptom?', in Greg Fealy and Sally White (eds), Expressing Islam: religious life and politics in Indonesia (Singapore: Institute of Southeast Asian Studies, 2008), pp. 174-91. 
Thus, the MMI code fully ignores the question of the government's form or its ideological foundations, focusing instead on legal regulations to be followed by 'every citizen on the territory of the Unitary State of the Republic of Indonesia'. This compilation of a sharia-based criminal code was first drafted after the August 2000 foundation meeting, and later presented as the Garis-garis besar Syariat Islam in July 2002, when parliament was yet again discussing a constitutional amendment to re-introduce the Jakarta Charter. $^{64}$

Where pre-1948 Kartosuwiryo, and Zainal Abidin Ahmad and Isa Anshary in the 1950s, had been concerned with the structure of a state that could harmonize Islamic principles with the needs of a modern state, the MMI and post-Roem-van-Royen-Agreement Kartosuwiryo solely focused on establishing a comprehensive Islamic law, demanding that the Indonesian state approximate it, paying little attention to government structure.

It is therefore because of historical circumstances that Kartosuwiryo turns out to be more relevant to twenty-first century reformulations of Islamic polity than to his own contemporaries writing in the 'consolidation' years.

\section{Comparing the Codes: Crimes and punishments}

Reflecting the classic distinction between crimes and punishments, both the NII and MMI codes offer a presentation of qisas, diya, ta'zir, and hudud. It is indicative of the respective socio-political context that the NII code focuses mostly on killings and banditism, and the MMI's on sexual offences.

In the NII text qisas is obligatory for the crime of killing a person that the law does not allow to be killed, and for the wounding that impairs reasoning capabilities (quoting Qur'an 5:45). Diya, instead, could be requested if the heirs of the victim were to give forgiveness, or in case of non-impairing wounding. Ta zir is prescribed for the killing of a person who it was lawful to kill, but who was killed before the imam or his representatives had passed the sentence.

Shafi'i jurisprudence prohibited applying qisas for the killing of a dhimmi, and such offence is punished in the NII code by light compensation (diya mukhaffafah). Qisas, however, is also forbidden in this code on the father of the victim, a practice that is otherwise usually allowed by the Shafi'i and Maliki schools. ${ }^{65}$ Another discrep-

64 'Proposal for a Criminal Code'. Fauzan Al-Anshari, KUHP Syariah.

65 J. Schacht, Kịsas, EI2. 
ancy is in the distinction applied to 'intentional', 'unintentional', and 'apparently intentional' killings, as mainstream Shafi'i legal thought does not require the intention to kill for qisas. ${ }^{66}$ According to the NII text 'light compensation' was permitted for intentional killing when apologies were offered to - and accepted by - the relatives of the victims, and the same punishment is prescribed for unintentional killing - either 100 camels or 16,000 golden dinar. The amputation of a single limb equalled 50 camels in compensation, two body-parts 100 camels, and a wound on the head 5 camels. In the MMI code these internal distinctions in compensation have disappeared, replaced instead by differentiations between compensation for a male Muslim victim, a female Muslim, and a kafir. the diya is fixed at 100 camels, 1,000 golden dinar, or 12,000 silver dirham for the life of a Muslim male or the loss of two limbs, while it is half for a Muslim woman, and the sum is further halved if the victim is a non-Muslim (and no differentiation is made between a dhimmi and a kafir).

Hudud offences are those crimes that break the limits (Arabic hadd, hudud) of what God has allowed. Tradition regards these offences as having fixed, unchangeable penalties, as these are God's own right. Illicit sexual intercourse $\left(z i n a^{\prime}\right)$, false accusation of zina' (qadhf), drinking alcohol, theft and robbery, and apostasy (irtidad, murtad) are all mentioned and discussed in the two texts. Both prescribe stoning for a married adulterer, although the NII code also includes the possibility of heavy compensation to be made in the case of the married adulterer, and 100 lashes (or banishment) in punishment for the unmarried one. ${ }^{67}$ The NII sanctions discretional punishment for bestiality and sodomy, with the latter reflecting the Hanafi school rather than the Shafi'i ${ }^{68}{ }^{6}$ whilst the MMI assimilates sodomy to zina' and changes the punishment for bestiality from ta'zir in 2002 to stoning in 2005. It should not surprise that the MMI code includes several additional articles on unacceptable sexual practices when compared with Kartosuwiryo's text. The inclusion of articles on lesbianism, necrophilia, and incest, as MMI's efforts to pass an Islamic criminal code, cannot be discerned from the general attempt of Islamist groups to impose

66 J. Schacht, Katl, EI2.

67 'Proposal for a Criminal Code', point no. 17; Fauzan Al-Anshari, KUHP syariah, point no. 16; Qanun asasy Negara Islam Indonesia, AABRI DI no. 9, point no. 12.1.

Another discrepancy between Pinardi's copy and AABRI DI no. 9 regards the crime of zina' Unless it was a typo, in Pinardi (who, in my opinion, uses a later text) the code appears to deal with the crime of adultery in a more progressive way, as article 18 does not suggest stoning, banishment, or imprisonment as forms of punishments.

68 R. Peters, Zina, EI2. 
Muslim standards of moral conduct, as also evidenced by the antipornography bill that was passed in 2009. For zina'accusations, the Hukum pidana required four male witnesses who had witnessed the sexual act (kelihatan masuk dan keluarnya) for the specific intention of testifying in court. The MMI code, on the other hand, requires no such burden of proof; in both codes he who accuses without satisfying the requirements is to be punished with 80 lashes.

The NII code punishes the drinking of alcohol with 40 lashes according to Shafi'i tradition, but the MMI incorporates Caliph Umar Ibn al-Khattab's decree that the lashes number up to 80, thus stipulating a punishment between 40 and 80 lashes; plus, in 2005, the addition of death penalty for he who is convicted for a fourth time. ${ }^{69}$ An interesting deviation from traditionally accepted jurisprudence, and an indication that this NII code was adapted to local understandings, is an article specifying that he who drank arak or other kinds of alcohol as a medical treatment and under the suggestion of a doctor should be exempted from the punishment. It should also be noted that neither the NII nor the MMI codes prohibit gambling.

The MMI code bears witness to the deep transformations in Islamic practice since the religious revival of the 1980s, as the evidence of cultural adaptation present in Kartosuwiryo's code, including the categorization of wandu and the permission to drink alcohol whenever prescribed by a doctor, have disappeared.

In the NII code, the article on robbery and theft (here described as baigal dan pencurian) prescribed execution by crucifixion for he who accidentally kills during a robbery, simple death for he who kills without seizing the goods, amputation of the right hand and left foot for he who robs without shedding blood, and ta'zir for he who scares travellers without causing any damage. Amputation was also the punishment for a person who stole up to $1 / 4$ of a dinar, a prescription that reflects Shafi'i tradition. Finally, he who killed while defending himself (daf'ul-sial), his belongings, or his wife's honour was exempted from punishment. In the NII code, as well as in the MMI ones, apostasy is treated in full accordance with, and acknowledgement of, books of figh (sebagaimana jang termaktub dalam kitab2 Fiqih): in the event that the order to repent went unheard, the apostate was to be punished with death. ${ }^{70}$

Comparing the treatment of hudud crimes and punishments it is evident that between 2002 and 2005 the MMI had further radicalized its position: the act of theft (sariqah) is punished in 2002 
with the amputation of the right hand and left foot for the first and second offences respectively, and with 'beating with a piece of wood or imprisonment for a term determined by the judge to give the convicted the opportunity to repent to God' for the third and subsequent ones. In 2005, however, the last clause is replaced with three more, specifying the amputation of left hand and right foot for the third and fourth offences, and eventually death for the fifthtime offender. In Kartosuwiryo's code this latter clause prescribes banishment, and the offence itself is referred to as pencurian. ${ }^{71}$ The second hudud crime taken into consideration by the MMI is hirabah, which is explained as civil disturbance and seems to correspond with the NII's baigal in its description of both offence and punishment. $^{72}$

Although scattered throughout the text, the NII code offers detailed regulations to meet most needs of society, focussing on those particularly relevant for a society in a state of war. Muslim fighters were allowed to withdraw when outnumbered, as preventing damage should take precedence over the acquisition of benefits (quoting $Q$ 8:1, 15). When fighting the infidels, Muslims could retreat if outnumbered 10 to 1 or 2 to 1 by the enemy (quoting $Q$ 8:65-66). Those who withdrew from the battlefield under any other circumstance were to be banished (quoting Q 8:16). The last article prescribed that the corpses of infidel enemies (as well as apostates) were to be buried for hygienic reasons; those executed whilst pronouncing the shahada were to be considered Muslims, and thus attended to as prescribed. Finally, Muslims who had died in battle or within 24 hours of being wounded were to be considered shahid dunia akhirat, or martyrs.

\section{BEYOND CONDEMNATION AND GLORIFICATION}

In addition to the views of Kartosuwiryo expressed in the sections above, in recent years efforts have been made to bring the complexities of Kartosuwiryo's career back under the spotlight. A first attempt to achieve balance can be seen in a 2006 publication titled Kearifan guru bangsa: Pilar kemerdekaan ('The fathers of the nation: Pillars of independence'). In this illustrated volume, Kartosuwiryo

71 'Proposal for a Criminal Code', point nos.10-11; Fauzan Al-Anshari, KUHP syariah, point no. 27; Qanun asasy Negara Islam Indonesia, AABRI DI no. 9, point no. 21.

72 'Proposal for a Criminal Code', point no. 14; Fauzan Al-Anshari, KUHP syariah, point no. 12; Qanun asasy Negara Islam Indonesia, AABRI DI no. 9, point no. 21. 
is represented alongside Amir Sjarifudin, Muhammad Husni Thamrin, Hadji Misbach, Mohammad Hatta, Soekarno, Tan Malaka and other leading representatives of the revolution, for the first time placing him in a wider hall of fame.

Kartosuwiryo is the subject of two chapters, titled 'Before the Darul Islam' and, 'A sad sequence', which point to the evolution of his approach to politics. The author singles out the pivotal shifts in Kartosuwiryo's career, from being Tjokroaminoto's disciple, to his move to West Java and his rising concerns for peasants' grievances and anti-colonial feelings which were channelled in the Darul Islam, to his eventual establishment of the Soeffah. Kartosuwiryo's understanding of Islam is represented as Arab-inspired, and the Soeffah as a work-camp whose strict regime caused his political failure, imprisonment and, eventually, cost him his life. The importance of this work lies in the fact that Kartosuwiryo is placed amongst officially recognized nationalist leaders, yet the simplification of his character has omitted his mysticism, in favour of highlighting an 'Arab orthodoxy'. ${ }^{73}$

A reflection is necessary on the most recent engagement of a 'mainstream' publication with Kartosuwiryo and the Darul Islam's history and legacy. In 2010 the special 'Independence Day' issue of Tempo was fully dedicated to Kartosuwiryo, covering everything from his political career to his contemporary following. These articles were reprinted in 2011 as a booklet that was part of a Gramedia book series 'Islamic leaders of the early independence period' (Tokoh Islam di awal kemerdekaan), which also included volumes on Daud Beureueh, Muhammad Natsir and Wahid Hasjim. ${ }^{74}$

What is noteworthy here is the editors' choice of two different covers for the Indonesian and English editions of the Tempo issue, which points to the difficulty that a renowned liberal magazine faces in attempting to ensure compliance with local and international understandings of political Islam in the twenty-first century.

While the Indonesian cover has Kartosuwiryo looking assertive, with the title 'Kartosuwiryo: Dreaming the Islamic state', the English edition features a pensive and troubled-looking Kartosuwiryo with the title, 'Kartosuwiryo: An impossible dream'. ${ }^{75}$ This divergence shows not too subtly how the magazine intended to offer what the readership expected: for the Indonesian audience, the editors neither condemned nor glorified the struggle for political

73 Suryana Sudrajat, Kearifan guru bangsa: Pilar kemerdekaan, (Jakarta: Erlangga, 2006).

74 Tempo, Kartosoewirjo, mimpi negara Islam. Seri buku Tempo: Tokoh Islam di awal kemerdekaan (Jakarta: Gramedia, 2011).

75 Majalah Tempo, August 18-24, 2010; English and Indonesian editions. 
Islam, while for the Western audience they made a strong statement about the infeasibility of achieving an Islamic state in the past as well as today.

Kartosuwiryo's memory - and its management - are emblematic of Indonesia's Islamic identity. Whether we look at family connections, territorial expansion or historical and ideological references, Kartosuwiryo and the Darul Islam are constant elements in the Islamist as much as the secular discourse. Yet the dominant image of Kartosuwiryo and the Darul Islam is a magnified one, of Kartosuwiryo as imam of the Negara Islam Indonesia, commander of the Tentara Islam Indonesia and crafter of an anti-Pancasila unitary Republic movement. But this is a picture only representative of a part of his political life. Those who hail him as a martyr and a hero differ from those who call him an enemy of the state or a terrorist only in perspective; both sides see Kartosuwiryo through their own self-interested filters. But Kartosuwiryo's historical relevance lies in his advocacy of non-cooperation with the Dutch, his dedication to an unshakably nationalist movement committed to absolute and uncompromising freedom from colonization and his framing the struggle for independence in Islamic terms. His legacy, however, is inextricably linked with the violent turn of his movement, because of which Islam lost its chance to become a prominent factor in national politics.

The violent evolution of the Darul Islam tainted the image of Islam as a political ideology, further pushing away the chance to realize an Islamic state. The portrayals of Kartosuwiryo and his movement need to be analysed amidst the changing context of Indonesian politics, from the revolution and Soekarno's subsequent consolidation of the Pancasila state, through the army's rising power and co-optation policies and Suharto's rapprochement with Islam and eventual fall, to the emergence of a new wave of Islamization of Indonesia's society.

The political development of Indonesia as an autocratic, non-confessional state, in which the army held control over the government and society for most of its existence, led to such a crystallization of understandings of Kartosuwiryo's actions and goals that his complexities were eventually reduced to an over-simplified dichotomy that could only be challenged after the passing of several decades and dramatic political transformations. 